\title{
空間記憶における海馬下位領域(CA1，CA3，歯状回)の 機能的分化と機能的連携
}

\author{
○岡田佳奈 ${ }^{1} \cdot$ 岡市廣成 ${ }^{2}$ \\ ( ${ }^{1}$ 同志社大学文学研究科, 日本学術振興会 $\cdot 2$ 同志社大学文学部) \\ Key words: Morris 型水迷路, 意味記憶, エピソード記憶
}

目的

ヒトの海馬は，宣言記憶に関与するといわれいる(Schacter \& Tulving, 1994; Squire \& Knowlton, 1993)。宣言記憶は , 意味 記憶とエピソード記憶に分類することができるが，両記憶に 関与する脳領域や両記憶の獲得あるいは再生される際のメカ ニズムについては議論が残されている。一方，げっ歯類の海 馬は, 空間記憶に関与することが明らかである(O'Keefe \& Nadel, 1978)。これら海馬依存型記憶間の橋渡しをし，動物乇 デルにおいて, 神経生理学的観点から意味記憶とエピソード 記憶の関係性について検討することには意義がある。

本実験では，特徵的な一方向性神経投射の見られる海馬下 位領域 CA1, CA3 および歯状回がどのような機能的関係性に よって空間記憶の形成に関るのかを明らかにする。光の際， 空間記憶課題として,Morris 型水迷路課題と,DMP 課題(Steel \& Morris, 1999)を用いた。Morris 水迷路課題は同じ位置の逃 避台への逃避訓練を複数回繰り返す課題であり，これを意味 記憶に関係する課題であると考えた。一方, DMP 課題は, 遅 延場所合せ手続きを用いた課題であるが，この課題における 逃避台の位置は，訓練日ごとによって全く異なっており，1 試行学習の成立を測定できるので, エピソード記憶に関係す る課題として考えた。

\section{方 法}

被験体: Wistar 系 albino ラットのオス 49 匹を使用した。ラッ 卜をControl 群 9 匹,Hipp 群 11 匹,DG 群 9 匹,CA3 群 9 匹， CA1 群 11 匹に分け，手術実施後にMorris 水迷路課題の訓練， 引き続き DMP 課題の訓練を実施した。なお，全ての実験は， 同志社大学動物実験ガイドラインに沿って実行された。

装置: Morris 型水迷路課題, DMP 課題両課題において, 同じ 実験室内に直径 $142 \mathrm{~cm}$, 壁の高さ $40 \mathrm{~cm}$ のポリエチレン製円 形プールをした。墨濁した水を深さ $12 \mathrm{~cm}$ まで満たし，逃避 台として, 直径 $11 \mathrm{~cm}$ の黑色の円柱を, 水面から見えないよ う水面下約 $2 \mathrm{~cm}$ に設置した。実験室内には壁面上のポスター や備え付けの棚などの手掛かりがあつた。

方法: a) 組織学的手法 CA1 群, CA3 群, Hipp 群に対して ibotenic acid, DG 群に対して colchicine を, CA1, CA3, DG, $\mathrm{Hipp}(\mathrm{CA} 1+\mathrm{CA} 3+\mathrm{DG})$ に対して注入し，乥れ攵れ神経毒損傷し た。神経毒損傷法の実施は，Jarrad(1989)の方式に従った。実 験終了後, ラットの脳切片を得てニッスル染色し，損傷部位 を光学顕微鏡下で検索した。

b) 行動学的手法 Morris 型水迷路課題では, ラットの逃避す る逃避台位置は訓練期間(7 日間)を通じて一定であった。ラッ 卜は，1日 4 試行を 1 ブロックとして訓練された。ブロック 内の 4 試行で異なるスタート位置を疑似ランダムに割り当て た。試行間隔は約 30 分だった。訓練終了日の翌日, プローブ テストを行った。プローブテストでは, プールから逃避台を 取り除き，60 秒間自由に泳がせた。光の後, Steele \& Morris(1999)の手続に従って DMP 課題を行った。ラットは, 1 日 4 試行で連続 9 日間テストされた。逃避台の位置は，1 日 4 試行の間同じだったが , 毎日全く別の場所に移動した。 Trial1 と Trial2 の間の試行間間隔(ITI)は , $5 \mathrm{sec}, 20 \mathrm{~min}, 2 \mathrm{hr}$ の

いずれかを疑似ランダムな順序で割り当てたが ,Trial2 ,Trial3，

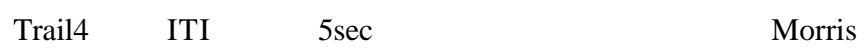
型水迷路課題と同樣に試行毎に変化させた。

結 果

a) 組織学的手法 CA1, CA3, DG, Hipp 群の標的部位が光れぞ れ損傷されたが, 腹側に組織が残存する例か数匹あった。DG 群ではCA1 のピペット通過位置にに軽微な損傷が見られた。 b) 行動学的手法 Morris 型水迷路課題の訓練期間中における 逃避潜時は DG 群が最も長く, Hipp 群 CA1 群が光れ続き， CA3 群と Control 群が最も短かった(Fig 1)。プローブテストに おける逃避台位置通過回数によると, Hipp, DG, CA1 群は, 逃 避台位置をあまり訪 れなかったが， CA3,Control 群は訪 れた。DMP 課題の ITI $15 \mathrm{sec}, 20 \mathrm{~min} の$ 試行では DG 群のみ が Trial1 から Trial2 における潜時の減少 を示さなかったが， ITI $2 \mathrm{hr}$ の試行では Hipp, DG, CA1 , CA3 群が Trial1 から Trial2 における潜時 の減少を示さなかっ た。

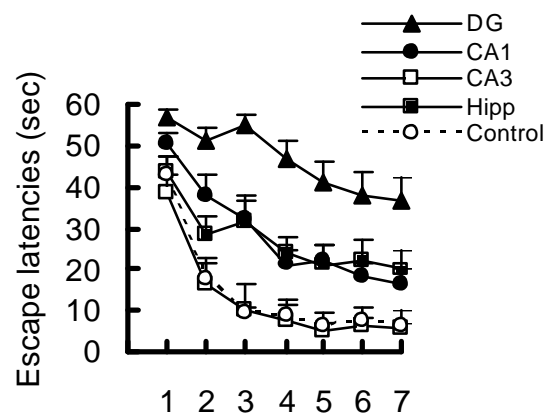

Blocks of 4 trials

Fig 1. Morris 型水迷路における逃避潜時

考 察

Morris 水迷路課題では, Hipp 群, CA1 群, DG 群が逃避台 位置を正確に学習しなかったが,CA3 群は,Control 群と同樣 に学習した。DMP課題ではDG 群は試行間間隔に関係なく， 逃避台の位置を正しく記憶していなかったが , Hipp 群 , CA1 群およびCA3 群は, 試行間間隔の長い条件で成績が悪くなる 遅延依存型の記憶障害を示した。まず，このことから，少な くとも記憶対象となる事象から短い時間しか経っていない 場合，CA3 は重要な役割を果たしていない。特にCA3 は Morris 水迷路課題の遂行には関与していないことから, 意味 記憶ではなく, 記憶事象の生起からしばらく経った場合の工 ピソード記憶の形成に関係するものと思われる。また，CA1 についても，エピソード記憶形成のごく初期の頃には関与し ないのかも知れない。歯状回に関しては, 意味記憶にもエピ ソード記憶にも関係していることが示される。また歯状回を 損傷したラットは海馬全体を損傷したラットよりも重篤に 意味記憶とエピソード記憶の形成障害を示したため, 歯状回 は他の海馬下位領域の機能に対して重要な関与を行ってい る可能性がある。これは, むしろ海馬内の CA1 の役割を中心 的と考える Yeckel et al. (1990)の feedforward 仮説とは異なる。 Yeckel et al. の説は, 海馬内回路と皮質, 特に嗅内皮質との関 連を重視したものであり, 本実験結果からは, 海馬と皮質下 組織との関連を視野に入れる必要性が示唆される。

(OKADA Kana, OKAICHI Hiroshige ) 